\title{
Oral health profile of participants of an elderly cohabitation program in the state of Santa Catarina, Brazil
}

\author{
Perfil de saúde bucal dos participantes de um programa de convivência de \\ idosos em Santa Catarina, Brasil
}

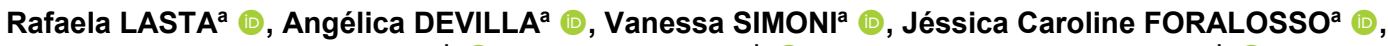

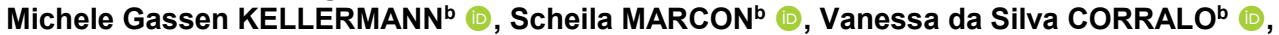 \\ Sinval Adalberto RODRIGUES-JUNIOR ${ }^{\mathbf{b}^{*}}$ (i) \\ ${ }^{a}$ Cirurgiã-dentista, Chapecó, SC, Brasil \\ ' UNOCHAPECÓ - Universidade Comunitária da Região de Chapecó, Área de Ciências da Saúde, Chapecó, SC, Brasil
}

How to cite: Lasta R, Devilla A, Simoni V, Foralosso JC, Kellermann MG, Marcon S, Corralo VS, Rodrigues-Junior SA. Oral health profile of participants of an elderly cohabitation program in the state of Santa Catarina, Brazil. Rev Odontol UNESP. 2019;48:e20190061. https://doi.org/10.1590/1807-2577.06119

\begin{abstract}
Resumo
Introdução: Programas de convívio e interação social tem melhorado vários aspectos da qualidade de vida de idosos. Objetivo: Este estudo observacional avaliou a saúde bucal e a percepção de saúde bucal de participantes de um programa de convívio de idosos em Santa Catarina, Brasil. Material e método: Duzentos e trinta e cinco participantes do programa Cidade do Idoso foram examinados/entrevistados por estudantes calibrados. 0 exame bucal considerou: índice de dentes cariados, perdidos e obturados (CPO-D), Índice Periodontal Comunitário (IPC), índice de Perda de Inserção Periodontal (PIP), uso e necessidade de prótese e presença de lesões de mucosa bucal. A percepção de saúde bucal foi verificada pelo Índice de Avaliação de Saúde Bucal Geriátrica (GOHAI). Os dados foram analisados com estatística descritiva e teste qui-quadrado $(\alpha=0,05)$. Resultado: 0 CPO-D médio foi de 24,3 dentes, com ênfase à categoria 'perdidos'. Necessidade de prótese superior e inferior correspondeu a 53,6 e $71,1 \%$, respectivamente; $55 \%$ apresentaram lesões de mucosa bucal. Uma percepção de saúde bucal moderada prevaleceu (43\%), com um escore médio do GOHAI de 29,9. Uma percepção negativa nas dimensões física e dor/desconforto foi estatisticamente associada com a necessidade de prótese inferior $(\mathrm{p}<0,05)$. Conclusão: Os participantes do programa Cidade do Idoso apresentaram uma saúde bucal precária e uma percepção de saúde bucal predominantemente moderada. A necessidade de prótese inferior foi associada a uma percepção negativa de saúde bucal.
\end{abstract}

Descritores: Idoso; saúde bucal; odontologia.

\begin{abstract}
Introduction: Cohabitation and social interaction programs have been shown to enhance several aspects of the quality of life of the elderly. Objective: This observational study assessed the oral health and oral health perception of participants of an elderly cohabitation program in the state of Santa Catarina, Brazil. Material and method: Calibrated dental students examined/interviewed 235 participants of the program. The oral examination considered Decayed, Missing, and Filled Teeth (DMFT) index, Community Periodontal Index (CPI), Periodontal Attachment Loss (PAL), use and need of prostheses, and presence of oral mucosal lesions. Oral health perception was verified with the Geriatric Oral Health Assessment Index (GOHAI) questionnaire. Data were analyzed with descriptive statistics and chi-square test $(\alpha=0.05)$. Result: The mean DMFT index was 24.3 teeth, with emphasis on the 'Missing' category. Upper and lower prosthetic needs were 53.6 and $71.1 \%$, respectively. Fifty-five per cent of participants presented oral mucosal lesions. Moderate oral health perception prevailed (43\%), with mean GOHAI score of 29.9. The negative perception on physical and pain/discomfort dimensions was statistically associated with lower prosthetic need $(p<0.05)$. Conclusion: The participants of the cohabitation program presented poor oral health and prevalence of moderate oral health perception. Lower prosthetic need was associated with negative perception.
\end{abstract}

Descriptors: Elderly; oral health; dentistry. 


\section{INTRODUCTION}

Population aging is a recent global phenomenon involving both developed and developing countries. In Brazil, for instance, life expectancy changed expressively in the $20^{\text {th }}$ century, with significant increase from 1900 to 1950 and 2000 (35, 43, and 68 years old, respectively). Estimations are that the life expectancy of Brazilians in 2025 will be of 80 years old 1 .

This aging tendency has required adjustments in health care services, increasing the focus on health problems of the elderly and including the demand for interdisciplinary approaches. In this context, the poor oral health profile of Brazilian elderly people ${ }^{2}$ has called attention of other health professionals who interact with this population more often than dentists ${ }^{3}$. Their concern is because oral health may affect and be affected by systemic health, generating physical and psychosocial effects 4 .

Historically, individual or collective actions toward the oral health of the elderly population have been scarce and poor ${ }^{5}$, resulting in high indexes of tooth loss and functional, social, and psychological consequences 6 . In addition, elderly people used a surgical-restorative model of dentistry with a highly mutilating and cumulative character6.

Current dentistry uses an approach that is less invasive and more preventive. Several oral diseases may be avoided through preventive and educational measures to the elderly. For Sheiham, Watt ${ }^{7}$, oral diseases present common risk factors of other important chronic diseases, such as cardiovascular diseases, cancers, and lesions of other origin. Therefore, a preventive interdisciplinary approach involving health professionals and other sectors of society may provide satisfactory results to this age segment.

Programs dedicated to social interaction specifically for the elderly are opportunities to disseminate interdisciplinary work and enhance the positive response to satisfactory preventive health practices ${ }^{8}$. In Brazil, most programs are held at universities, such as the universities for senior citizens (UnATIs) programs ${ }^{9}$. In the city of Chapecó, Santa Catarina, Brazil, the municipal government maintains a program called City of the Elderly (Cidade do Idoso), since 2008. The participants go through a general health check-up before participating in activities that involve gymnastics, yoga, pilates, supervised walking, and water aerobics. The program also offers lunch, music and dance classes, various games, as well as literacy and basic computer classes to the elderly ${ }^{10}$.

Although there are similar programs in Brazil, they differ significantly as to their concepts, goals, and maintainers, which makes each program unique. Therefore, this study aimed to assess the oral health profile of elderly people participating in the City of the Elderly program, as well as to verify whether the oral health perception of these participants correspond to the oral health status objectively assessed.

\section{MATERIAL AND METHOD}

This cross-sectional study was performed in the City of the Elderly program, in Chapecó, Santa Catarina, Brazil, from March 2016 to November 2016. The study proposal was designed according to the World Medical Association Declaration of Helsinki and it was approved by the institutional Ethics Committee, under protocol no. 1.266.459.

The population of the study included the participants of the City of the Elderly program (approximately 1000 participants, as provided by the program administrator) who presented a minimum frequency of $70 \%$ in the activities with which they were involved. A sample size of 278 subjects was calculated using the finite population formula in an online calculator (Select Statistical Services) ${ }^{11}$, as well as the following parameters: $50 \%$ sample proportion estimate, $5 \%$ sampling error, and 95\% confidence interval. Subjects older than 60 years who accepted to participate and did not present neurodegenerative conditions previously diagnosed were included in the study. 
Sex (male/female) was collected as the independent variable. Oral health was assessed considering the variables proposed by the World Health Organization ${ }^{11}$, as follows:

i) Use and need of upper and lower dental prosthesis.

ii) Decayed, missing, and filled teeth (DMFT) index subdivided into crown and root. A tooth was considered decayed when there was visual evidence of cavity that could be confirmed in the occlusal, buccal, and lingual aspects of the tooth by probing with the CPI probe.

iii) Edentulism and lack of functional dentition. Edentulism was considered the lack of all teeth, while lack of functional dentition considered the existence of less than 20 teeth $^{12}$.

iv) Community Periodontal Index (CPI), which was assessed as the presence and depth of periodontal pockets, subgingival calculus, and gingival bleeding in index teeth per sextants at probing, with a specially designed probe. The CPI probe is designed with a $0.5 \mathrm{~mm}$ ball tip, a black band between 3.5 and $5.5 \mathrm{~mm}$, and rings or marks at 8.5 and $11.5 \mathrm{~mm}$ (25). The CPI was coded as 0 (healthy), 1 (bleeding on probing), 2 (subgingival calculus detected during probing, but the black band of the probe is entirely visible), 3 (periodontal pocket of $4-5 \mathrm{~mm}$ and gingival margin within the black band of the probe), 4 (periodontal pocket of $6 \mathrm{~mm}$ or more and black band of the probe not visible), X (sextant excluded, less than two teeth present).

v) Periodontal Attachment Loss (PAL) assessed by probing of the same index teeth. The exposure of the cemento-enamel junction (CEJ) is taken as reference, determining the presence of gingival recession. The PAL was coded as 0 (attachment loss of 0-3 mm, CEJ not visible, and CPI between 0-3 mm), 1 (attachment loss of 4-5 mm, CEJ within the black band), 2 (attachment loss of 6-8 $\mathrm{mm}$, CEJ between the upper limit of the black band and the $8.5 \mathrm{~mm}$ ring), 3 (attachment loss of $9-11 \mathrm{~mm}$ and CEJ between the 8.5 and $11.5 \mathrm{~mm}$ rings), 4 (attachment loss of $12 \mathrm{~mm}$ or more, CEJ beyond the $11.5 \mathrm{~mm}$ ring), $\mathrm{X}$ (sextant excluded, less than two teeth present). For both periodontal indexes, the worst condition was registered.

vi) Presence of oral mucosal lesions, categorized as normal mucosa or presence of lesion. Upper and lower labial mucosa and labial sulcus, commissures of dorsal and ventral surfaces and margins of the tongue, oral mucosa, palate, floor of the mouth, retromolar area, and upper and lower gingiva were evaluated. The presence of lesion was determined based on clinical criteria. There was no biopsy to confirm the diagnosis, but patients with oral mucosal lesions were referred to university dental clinics.

The self-perception on oral health was collected through the application of the Portuguese version of the Geriatric Oral Health Assessment Index (GOHAI) ${ }^{13}$, which contains 12 3-point Likert scale questions involving physical, psychosocial, and pain/discomfort dimensions. The simple sum of points corresponding to the answers (1-Always; 2-Sometimes; 3-Never) generate a final selfperception score, which may be high (34-36 points), moderate (30-33 points), or low ( $<30$ points).

A specialist in operative dentistry trained four third-year dental students and slide presentations and discussion sessions were used. Calibration tests were performed in 12 elderly people of both sexes. A Kappa coefficient of agreement of 0.831-1.00 between the examiners and the gold standard examiners was achieved.

The clinical examinations were performed in the healthcare center of the program using sterile gauze, dental mirror, and CPI probe, under artificial light. The examiners applied the GOHAI questionnaire in person.

The data were tabulated in the Statistical Package for Social Sciences (SPSS) 20.0 and analyzed using descriptive statistics and chi-square test $(\alpha=0.05)$. The use and need of prostheses were dichotomized to help establishing associations with sex and oral health perception. 


\section{RESULT}

A total of 235 participants were examined/interviewed. One hundred and fifty (63.8\%) were women. Considering the sample achieved was lower than the sample size estimated, the test power for most outcomes was calculated using the $\mathrm{G}^{*}$ Power 3.1 package (Universität Düsseldorf, Düsseldorf, Germany). The two-tailed post-hoc function of one-sample t-test and one-proportion binomial test were used, confronting data with the results of both the Brazilian Oral Health Survey SBBrasil $^{2}$ and Costa et al. ${ }^{14}$ for the dimensions of the GOHAI. The lowest test power achieved varied between 0.4 and 0.447 for subgingival calculus and shallow and deep pockets, in the CPI index. For all other variables, test power was $0.831-1.000$. Table 1 presents the results of the DMFT index and Table 2 presents the frequencies of the oral health assessment.

Table 1. Mean (SD) index of decayed, missing and filled teeth for crown and root of elders

\begin{tabular}{lccc}
\hline & Minimum & Maximum & Mean (SD) \\
\hline DMFT - crown & & & \\
Decayed & 0 & 4 & $0.17(0.57)$ \\
Missing & 0 & 28 & $21.6(7.61)$ \\
Filled & 0 & 20 & $2.6(4.07)$ \\
Total & 8 & 31 & $24.37(4.48)$ \\
DMFT - root & & & \\
Decayed & 0 & 9 & $0.13(0.73)$ \\
Missing & 0 & 28 & $21.59(7.64)$ \\
Filled & 0 & 7 & $0.26(0.89)$ \\
Total & 0 & 28 & $21.98(7.42)$ \\
\hline
\end{tabular}

Table 2. Results of oral health assessment $(n=235)$

\begin{tabular}{lcc}
\hline & $\mathbf{n}(\mathbf{\%})$ & $\mathbf{9 5 \%} \mathbf{C I}$ \\
\hline Prosthetic use & & \\
Upper arch & $217(92.3)$ & $88.9-95.7$ \\
Low arch* $(\mathrm{n}=234)$ & $180(76.6)$ & $71.2-82.0$ \\
Prosthetic need & & \\
Upper arch* $(\mathrm{n}=234)$ & $126(53.6)$ & $47.2-60.0$ \\
Low arch*(n=233) & $167(71.1)$ & $65.3-76.9$ \\
Edentulism & & \\
Yes & $99(42.1)$ & $35.8-48.4$ \\
No & $136(57.9)$ & $51.6-64.2$ \\
Lack of Functional dentition & & \\
Yes & $210(89.4)$ & $6.5-93.3$ \\
No & $25(10.6)$ & \\
DMFT - Crown & & $6.7-14.5$ \\
Decayed & $25(10.6)$ & $98.8-100.4$ \\
Missing & $234(99.6)$ & $43.0-55.8$ \\
Filled & $116(49.4)$ & $3.3-9.5$ \\
DMFT - Root & & $98.8-100.4$ \\
Decayed & $15(6.4)$ & $7.4-15.6$ \\
Missing & $234(99.6)$ & $-0.4-1.2$ \\
Filled & $27(11.5)$ & \\
Presence of mucosal oral lesion** & & \\
Lip & $13(5.5)$ & \\
Commissures & $1(0.4)$ & \\
\hline
\end{tabular}


Table 2. Continued...

\begin{tabular}{lcc}
\hline & $\mathbf{n}(\mathbf{\%})$ & $\mathbf{9 5 \%} \mathbf{C I}$ \\
\hline Buccal mucosa & $13(5.5)$ & $2.6-8.4$ \\
Retromolar area & $3(1.3)$ & $-0.1-2.7$ \\
Labial sulci & $1(0.4)$ & $-0.4-1.2$ \\
Alveolar ridge & $18(7.7)$ & $4.3-11.1$ \\
Hard palate & $109(46.4)$ & $40.0-52.8$ \\
Community Periodontal Index (CPI) & & \\
Normal & $15(6.4)$ & $3.3-9.5$ \\
Bleeding & $14(6.0)$ & $3.0-9.0$ \\
Calculus & $18(7.7)$ & $4.3-11.1$ \\
Shallow pocket & $2(0.9)$ & $-0.3-2.1$ \\
Deep pocket & $1(0.4)$ & $-0.4-1.2$ \\
Excluded sextant & $185(78.7)$ & $73.5-83.9$ \\
Periodontal Attachment Loss (PAL) & & \\
0-3mm & $27(11.7)$ & $7.6-15.8$ \\
4-5mm & $19(8.0)$ & $4.5-11.5$ \\
6-8mm & $2(0.9)$ & $-0.3-2.1$ \\
9-11mm & $1(0.4)$ & $-0.4-1.2$ \\
+12mm & $1(0.4)$ & $-0.4-1.2$ \\
Excluded sextant & $185(78.9)$ & $73.5-83.9$ \\
\hline
\end{tabular}

*Number of participants for the variable; ${ }^{* *}$ Based on clinical diagnosis/no complementary exam was performed.

One hundred and thirty participants (55.3\%) presented oral mucosal lesions. There was actinic cheilitis and fibroma in the lips, angular cheilitis in the commissures, leukoplakia and fibroma in the oral mucosa, leukoplakia in the retromolar region, and inflammatory hyperplasia in the labial sulcus. Inflammatory hyperplasia, fibrous hyperplasia, leukoplakia, erythroplakia, and hyperkeratosis were observed in the alveolar ridge and, in the hard palate, denture stomatitis was the most common lesion, followed by cases of hyperplasia by suction chamber.

Oral health perception was high for 52 participants (22.1\% - 95\%CI 16.8-27.8), moderate for 101 participants (43\% - 95\%CI 36.7-49.3), and low for 82 participants (34.9\% - 95\%CI 28.8-41.0). Table 3 presents the mean score for the different domains of the GOHAI. There were no significant associations between sex and use or need of dental prostheses, and edentulism or functional edentulism and oral health perception ( $\mathrm{p}>0.05)$.

Table 3. Distribution and percentage of total values of the GOHAl index in its domains

\begin{tabular}{lcc}
\hline & Possibilities of points & $\begin{array}{c}\text { Mean points } \pm \text { SD (\% of the } \\
\text { maximum value possible) }\end{array}$ \\
\hline Physical domain & $4-12$ & $9.97 \pm 2.99(83.2)$ \\
Psychosocial domain & $3-9$ & $7.1 \pm 1.76(78.7)$ \\
Pain/discomfort domain & $5-15$ & $12.8 \pm 3.55(85.3)$ \\
Total GOHAI & $12-36$ & $29.9 \pm 8.3(83.1)$ \\
\hline
\end{tabular}

There was a significant association between use $\left(\chi^{2}=29.523 ; p=0.0001\right)$ and need $\left(\chi^{2}=19.939\right.$; $\mathrm{p}=0.001$ ) of prostheses in the upper arch and the presence of oral mucosal lesion in the palate, which occurred in $43 \%$ of complete upper denture wearers and in $25.1 \%$ of those who needed complete dentures.

Table 4 presents the association between prosthetic need and the GOHAI questions on oral health perception. The need of upper dentures was not associated with oral health perception $(p>0.05)$. 
Table 4. Variables of the GOHAI index significantly associated to lower prosthetic need

\begin{tabular}{|c|c|c|c|c|}
\hline & \multicolumn{4}{|c|}{ Lower prosthetic need } \\
\hline & Needs (n/\%) & $\begin{array}{c}\text { Does not } \\
\text { need (n/\%) }\end{array}$ & $\chi^{2}$ & $\mathbf{p}$ \\
\hline \multicolumn{5}{|l|}{ GOHAI question } \\
\hline $\begin{array}{l}\text { G1. In the last } 3 \text { months, how often did you limit the kinds or } \\
\text { amounts of food you eat because of problems with your teeth or } \\
\text { dentures? }\end{array}$ & & & 9.770 & 0.008 \\
\hline Always & $31(13.2)$ & $2(0.9)$ & & \\
\hline Sometimes & $25(10.6)$ & $9(3.8)$ & & \\
\hline Never & $113(48.1)$ & $55(23.4)$ & & \\
\hline $\begin{array}{l}\text { G2. In the last } 3 \text { months, how often did you have trouble biting or } \\
\text { chewing any kinds of food? }\end{array}$ & & & 16.057 & 0.0001 \\
\hline Always & $49(20.9)$ & $6(2.6)$ & & \\
\hline Sometimes & $39(16.6)$ & $10(4.3)$ & & \\
\hline Never & $81(34.5)$ & $50(21.3)$ & & \\
\hline $\begin{array}{l}\text { G5. In the last } 3 \text { months, how often were you able to eat anything } \\
\text { feeling discomfort? }\end{array}$ & & & 9.120 & 0.010 \\
\hline Always & $34(14.5)$ & $3(1.3)$ & & \\
\hline Sometimes & $38(16.2)$ & $15(6.4)$ & & \\
\hline Never & $97(41.3)$ & $48(20.4)$ & & \\
\hline $\begin{array}{l}\text { G9. In the last } 3 \text { months, how often were you worried or concerned } \\
\text { about the problems with your teeth, gums or dentures? }\end{array}$ & & & 8.476 & 0.014 \\
\hline Always & $21(8.9)$ & $6(2.6)$ & & \\
\hline Sometimes & $38(16.2)$ & $5(2.1)$ & & \\
\hline Never & $110(46.8)$ & $55(23.4)$ & & \\
\hline
\end{tabular}

\section{DISCUSSION}

To the best of our knowledge, the City of the Elderly is the only program destined to the social interaction, learning, and health care of elderly people that is maintained by a municipal government in the Brazilian territory. The universities for senior citizens (UnATIs) programs currently represent the proposals closer to a university educational character ${ }^{9}$. Participants of the City of the Elderly program consider it a space to establish a new meaning to their life through the activities offered, in which they rediscover fun, dance, conversation, playing, and love.

Health monitoring is an integral part of the program, meaning the participants only take part in the activities after having their general health status monitored properly, but the program does not include oral health assessments. Therefore, it was expected that participants of the program would present problems similar to the general Brazilian elderly population. Our results indeed showed a slightly poorer oral health condition of the participants as compared with the Brazilian Oral Health Survey ${ }^{2}$ and other surveys performed in southern Brazil12,15. However, we observed that the oral health perception of the elderly did not correspond to their actual oral health status, which was poorer. Additionally, the association between lower prosthetic need and the low grading in physical and pain/discomfort dimensions indicates an obvious oral health care demand for satisfactory eating habits.

The poor oral health condition and treatment need observed in our study were expressed by high DMFT index, edentulism, prosthetic need, and presence of oral mucosal lesions, and they corroborate an oral health profile of the elderly in southern Brazil shown elsewhere ${ }^{2,15}$. According to the Brazilian Oral Health Survey, the general DMFT index of individuals aged 65-74 years is 27.5, with the "Missing" component accounting for $92 \%$ of the total index ${ }^{2}$. Our study identified $99.6 \%$ of missing teeth in the DMFT index. Consequently, a high percentage of null sextants was found during periodontal 
assessment (approximately 79\%), similar to a prior study ${ }^{16}$ and lower than the record of the Brazilian National Survey for the elderly in southern Brazil $(88.7 \%)^{2}$. Most of the existing teeth presented subgingival calculus $(7.7 \%)$ and periodontal attachment loss of $4-5 \mathrm{~mm}(8.0 \%)$ as the worst periodontal conditions.

Edentulism was found in $42 \%$ of our participants, while lack of functional dentition reached 89\%. This represents a chronic condition resulting from diseases and experiences lived in the course of life, which affects nutrition, phonation, chewing, aesthetics, and self-esteem ${ }^{5,12,17,18}$. It also indicates the resolution capacity of the public health system in managing oral health demands. Tooth loss is affected by biological, cultural, economic, and social factors ${ }^{5,19}$. Culturally, tooth loss has long been understood as a natural part of aging 6 . In addition, urgent oral health care for adults was usually limited to tooth extraction, leading to the burden of tooth loss 5 . Improvements in public oral health care, including the progressive offer of secondary and tertiary care, are recent. Therefore, time is required for verifying the full impacts of these improvements ${ }^{5,20}$. Functional edentulism was higher in our study than in another recent survey involving a southern Brazilian population ${ }^{12}$, which confirms the distance from the global goal of 2020 proposed by the World Health Organization, the World Dental Federation, and the International Association for Dental Research for half of the elderly population to present functional dentition (21 or more teeth) ${ }^{21}$.

The higher rate of upper denture wearers potentially relates to aesthetic and social aspects, considering that losing anterior teeth, mainly in the upper arch, affects social aspects such as smiling and speaking ${ }^{20}$. The use of complete upper dentures prevailed in our study $(77.0 \%)$, followed by use of removable partial dentures (14.1\%). Both percentages were higher than the means described in the National Survey SBBrasil for the elderly in southern Brazil $(65.3 \%$ and $11.1 \%$, respectively $)^{2}$. The use of complete upper dentures was associated significantly with the presence of denture stomatitis in the hard palate, which was the most prevalent oral mucosal lesion. Similarly, $25 \%$ of individuals needing complete upper dentures also presented such lesion. Denture stomatitis is the most common oral mucosal lesion in community-dwelling elderly people and it is characterized by an inflammatory condition of the denture-bearing mucosa, mostly associated with Candida colonization ${ }^{22}$.

More than $50 \%$ of participants presented some type of oral mucosal lesion and $69 \%$ of them presented denture stomatitis. Oral lesions have been described as highly prevalent in the elderly, especially denture stomatitis ${ }^{15}$. However, the presence of oral lesion was not associated with any domain of oral health-related self-perception. One potential explanation is that most lesions found are not likely to produce severe pain, which according to Melo et al. ${ }^{23}$ is an important element for the report of negative impact on the oral health-related quality of life of the elderly. Our study did not show malignant lesions, but the importance of periodic oral self-examinations from the elderly population should be highlighted.

The oral health perception of our participants was mostly moderate, revealing a discrepancy with their actual oral health condition. This discrepancy was also found in a previous study ${ }^{24}$ and it may be explained by personal values and beliefs that tend to naturalize the poor oral health of the elderly, leading to an overestimated oral health condition ${ }^{14}$. Additionally, considering the perspective of inclusion and social interaction provided by the program, difficulties faced due to oral problems might be potentially considered secondary. Moreover, the pain/discomfort dimension of the GOHAI corresponded to $85 \%$ of the total score, characterizing low pain perception in the sample studied. Living with chronic pain is also considered natural amongst the elderly ${ }^{14}$, so much that this condition should be acute enough to interfere with functional aspects and to grade the oral health perception of this age group as low ${ }^{23}$.

The psychosocial domain presented the lowest score in the GOHAI, corresponding to $78.7 \%$ of the total score possible and it was not associated with use or need of prostheses. This finding reinforces the fact that most of the prosthetic need was not associated with poor aesthetic issues 
of the prosthesis. On the contrary, physical and pain/discomfort dimensions were significantly associated with lower prosthetic need, revealing that most individuals needing a new lower denture limit types or amounts of food, present trouble biting or chewing food, feel discomfort while eating, and are concerned with problems in their teeth, gums, or dentures (Table 4). These findings agree with those by Silva et al. ${ }^{24}$, to whom the presence of functional dentition and the lack of need of complete dentures were associated to a more favorable oral health perception.

The participants of the City of the Elderly program present poor oral health, evidencing high tooth loss, high prosthetic need, and presence of oral mucosal lesion. The mean GOHAI score was 29.9 points, characterizing a prevalence of moderate oral health perception. The negative perception of physical and pain/discomfort dimensions was associated with lower prosthetic need.

\section{REFERENCES}

1. Fiedler MM, Peres KG. Capacidade funcional e fatores associados em idosos do Sul do Brasil: um estudo de base populacional. Cad Saude Publica. 2008 Fev;24(2):409-15. http://dx.doi.org/10.1590/S0102311X2008000200020. PMid:18278288.

2. Brasil. Ministério da Saúde. Projeto SB Brasil 2010: Pesquisa Nacional de Saúde Bucal: resultados principais [Internet]. Brasília: Ministério da Saúde; 2010 [citado 2016 Fev 16]. Disponível em: http://bvsms.saude.gov.br/bvs/publicacoes/pesquisa_nacional_saude_bucal.pdf

3. Gonsalves WC, Wrightson AS, Henry RG. Common oral conditions in older persons. Am Fam Physician. 2008 Oct;78(7):845-52. PMid:18841733.

4. Pessoa DMV, Pérez G, Marí-Dell'Olmo M, Cornejo-Ovalle M, Borrell C, Piuvezam G, et al. Comparative study of the oral health profile of institucionalized elderly persons in Brazil and Barcelona, Spain. Rev Bras Geriatr Gerontol. 2016 Oct;19(5):723-32. http://dx.doi.org/10.1590/180998232016019.160013.

5. Cardoso M, Balducci I, Telles DM, Lourenço EJV, Nogueira L Jr. Edentulism in Brazil: trends, projections and expectations until 2040. Cien Saude Colet. 2016 Apr;21(4):1239-46. http://dx.doi.org/10.1590/1413-81232015214.13672015. PMid:27076022.

6. Sá C, Ferretti F, Busato MA. Ensaios contemporâneos em saúde: uma perspectiva interdisciplinar. Chapecó: Argos; 2013. p. 129-41.

7. Sheiham A, Watt RG. The common risk factor approach: a rational basis for promoting oral health. Community Dent Oral Epidemiol. 2000 Dec;28(6):399-406. http://dx.doi.org/10.1034/j.16000528.2000.028006399.x. PMid:11106011.

8. Silva LRF. Da velhice à terceira idade: o percurso histórico das identidades atreladas ao processo de envelhecimento. Hist Cienc Saude Manguinhos. 2008 Mar;15(1):155-68. http://dx.doi.org/10.1590/S0104-59702008000100009. PMid:19241678.

9. Eltz GD, Artigas NR, Pinz DM, Magalhães CR. Panorama atual das Universidades Abertas à Terceira Idade no Brasil. Rev Kairós Gerodont. 2014 Dez;17(4):83-94.

10. Chapecó. Prefeitura Municipal de Chapecó. Cidade do idoso é referência internacional. [Internet]; 2013 [citado 2016 Fev 14]. Disponível em: https://www.chapeco.sc.gov.br/noticia/1628/cidade-do-idosoretoma-atividades-em-chapeco

11. World Health Organization - WHO. Oral health surveys - basic methods. 5th ed. Geneva: World Health Organization; 2013.

12. Ribeiro CG, Cascaes AM, Silva AER, Seerig LM, Nascimento GG, Demarco FF. Edentulism, severe tooth loss and lack of functional dentition in elders: a study in Southern Brazil. Braz Dent J. 2016 Jun;27(3):345-52. http://dx.doi.org/10.1590/0103-6440201600670. PMid:27224572. 
13. Carvalho C, Manso AC, Escoval A, Salvado F, Nunes C. Tradução e validação da versão portuguesa do Geriatric Oral Health Assessment Index (GOHAI). Rev Port Saude Publica. 2013 Dec;31(2):166-72. http://dx.doi.org/10.1016/j.rpsp.2013.10.002.

14. Costa EH, Saintrain MV, Vieira AP. Autopercepção da condição de saúde bucal em idosos institucionalizados e não institucionalizados. Cien Saude Colet. 2010 Set;15(6):2925-30. http://dx.doi.org/10.1590/S1413-81232010000600030. PMid:20922301.

15. Gaio EJ, Haas AN, Carrard VC, Oppermann RV, Albandar J, Susin C. Oral health status in elders from South Brazil: a population-based study. Gerodontology. 2012 Sep;29(3):214-23. http://dx.doi.org/10.1111/j.1741-2358.2011.00617.x. PMid:22486627.

16. Silva DD, Sousa ML, Wada RS. Autopercepção e condições de saúde bucal em uma população de idosos. Cad Saude Publica. 2005 Ago;21(4):1251-9. http://dx.doi.org/10.1590/S0102-311X2005000400028. PMid:16021263.

17. Gerritsen AE, Allen PF, Witter DJ, Bronkhorst EM, Creugers NH. Tooth loss and oral health-related quality of life: a systematic review and meta-analysis. Health Qual Life Outcomes. 2010 Nov;8(1):126. http://dx.doi.org/10.1186/1477-7525-8-126. PMid:21050499.

18. De Marchi RJ, Hugo FN, Hilgert JB, Padilha DM. Association between number of teeth, edentulism and use of dentures with percentage body fat in south Brazilian community-dwelling older people. Gerodontology. 2012 Jun;29(2):e69-76. http://dx.doi.org/10.1111/j.1741-2358.2010.00411.x. PMid:21054508.

19. De Marchi RJ, Hilgert JB, Hugo FN, Santos CM, Martins AB, Padilha DM. Four-year incidence and predictors of tooth loss among older adults in a Southern Brazilian city. Community Dent Oral Epidemiol. 2012 Oct;40(5):396-405. http://dx.doi.org/10.1111/j.1600-0528.2012.00689.x. PMid:22564001.

20. Azevedo MS, Correa MB, Azevedo JS, Demarco FF. Dental prosthesis use and/or need impacting the oral health-related quality of life in Brazilian adults and elders: Results from a National Survey. J Dent. 2015 Dec;43(12):1436-41. http://dx.doi.org/10.1016/j.jdent.2015.10.016. PMid:26523347.

21. Hobdell M, Petersen PE, Clarkson J, Johnson N. Global goals for oral health 2020. Int Dent J. 2003 Oct;53(5):285-8. http://dx.doi.org/10.1111/j.1875-595X.2003.tb00761.x. PMid:14560802.

22. Hilgert JB, Giordani JM, Souza RF, Wendland EM, D'Avila OP, Hugo FN. Interventions for the management of denture stomatitis: a systematic review and meta-analysis. J Am Geriatr Soc. 2016 Dec;64(12):2539-45. http://dx.doi.org/10.1111/jgs.14399. PMid:27889906.

23. Melo LA, Sousa MM, Medeiros AK, Carreiro AD, Lima KC. Factors associated with negative selfperception of oral health among institucionalized elderly. Cien Saude Colet. 2016 Nov;21(11):3339-46. http://dx.doi.org/10.1590/1413-812320152111.08802015. PMid:27828567.

24. Silva DD, Held RB, Torres SV, Sousa ML, Neri AL, Antunes JL. Self-perceived oral health and associated factors among the elderly in Campinas, Southeastern Brazil, 2008-2009. Rev Saude Publica. 2011 Dec;45(6):1145-53. http://dx.doi.org/10.1590/S0034-89102011000600017. PMid:21953025.

\section{CONFLICTS OF INTERESTS}

The authors declare no conflicts of interest.

\section{${ }^{*}$ CORRESPONDING AUTHOR}

Sinval Adalberto Rodrigues-Junior, Universidade Comunitária da Região de Chapecó, Área de Ciências da Saúde, CP 1141, Servidão Anjo da Guarda, 295-D, Efapi, 89809-900 Chapecó-SC, Brasil, e-mail: rodriguesjunior.sa@unochapeco.edu.br

Received: June 18, 2019

Accepted: August 5, 2019 